\title{
GMR
}

\section{Diversity among elephant grass genotypes using Bayesian multi-trait model}

\author{
D.A. Rossi ${ }^{1}$, R.F. Daher ${ }^{2}$, T.C. Barbé2, R.S.N. Lima ${ }^{3}$, A.F. Costa ${ }^{4}$, \\ L.P. Ribeiro ${ }^{5}$, P.E. Teodoro ${ }^{5}$ and L.L. Bhering ${ }^{5}$
}

${ }^{1}$ Faculdade Venda Nova do Imigrante, Venda Nova do Imigrante, ES, Brasil ${ }^{2}$ Laboratório de Melhoramento Genético Vegetal, Universidade Estadual do Norte Fluminense "Darcy Ribeiro", Campos dos Goytacazes, RJ, Brasil ${ }^{3}$ Universidade Federal de Alagoas, Campus Arapiraca, Arapiraca, AL, Brasil ${ }^{4}$ Instituto Capixaba de Pesquisa, Assistência Técnica e Extensão Rural, Centro Regional de Desenvolvimento Rural, Centro Serrano, Domingos Martins, ES, Brasil

${ }^{5}$ Laboratório de Biometria, Departamento de Biologia Geral, Universidade Federal de Viçosa, Viçosa, MG, Brasil

Corresponding author: P.E. Teodoro

E-mail: eduteodoro@hotmail.com

Genet. Mol. Res. 16 (3): gmr16039803

Received August 15, 2017

Accepted August 29, 2017

Published September 27, 2017

DOI http://dx.doi.org/10.4238/gmr16039803

Copyright $(2017$ The Authors. This is an open-access article distributed under the terms of the Creative Commons Attribution ShareAlike (CC BY-SA) 4.0 License.

ABSTRACT. Elephant grass is a perennial tropical grass with great potential for energy generation from biomass. The objective of this study was to estimate the genetic diversity among elephant grass accessions based on morpho-agronomic and biomass quality traits and to identify promising genotypes for obtaining hybrids with high energetic biomass production capacity. The experiment was installed at experimental area of the State Agricultural College Antônio Sarlo, in Campos dos Goytacazes. Fifty-two elephant grass genotypes were evaluated in a randomized block design with two replicates. Components of variance and the genotypic means were obtained using a Bayesian multi-trait

Genetics and Molecular Research 16 (3): gmr16039803 
model. We considered 350,000 iterations in the Gibbs sampler algorithm for each parameter adopted, with a warm-up period (burn-in) of 50,000 Iterations. For obtaining an uncorrelated sample, we considered five iterations (thinning) as a spacing between sampled points, which resulted in a final sample size 60,000 . Subsequently, the Mahalanobis distance between each pair of genotypes was estimated. Estimates of genotypic variance indicated a favorable condition for gains in all traits. Elephant grass accessions presented greater variability for biomass quality traits, for which three groups were formed, while for the agronomic traits, two groups were formed. Crosses between Mercker Pinda México x Mercker 86-México, Mercker Pinda México x Turrialba, and Mercker 86-México x Taiwan A-25 can be carried out for obtaining elephant grass hybrids for energy purposes.

Key words: Pennisetum purpureum; Biomass production; Bioenergy; Biomass quality

\section{INTRODUCTION}

Elephant grass (Pennisetum purpureum Schum.) is a perennial tropical grass of great importance, whose morphological characteristics present wide variability. It is a highly efficient species in the atmospheric $\mathrm{CO}_{2}$ fixation, producing more than $60 \mathrm{mg} / \mathrm{ha}$ per year (Morais et al., 2009), besides having fast vegetative growth (Gonçalves et al., 2012). Due to being a species with high potential for dry matter production and high photosynthetic efficiency, elephant grass has quantitative traits that favor the use of its vegetal biomass for an alternative energy source.

Vegetable biomass as an energy input has been gaining importance in the development of alternative energies in the energy matrix (Nass et al., 2007). Several crops have been evaluated for the energy generation from biomass, such as sugarcane, sorghum, maize, wheat, triticale, and Panicum virgatum L. (Boehmel et al., 2008; David and Ragauskas, 2010; Ra et al., 2012). In this sense, elephant grass stands out in the generation of thermal energy by the biomass combustion, because it has adequate quality characteristics and high biomass production (Morais et al., 2009; Ra et al., 2012; Fontoura et al., 2015).

Embrapa Gado de Leite conserves an elephant grass germplasm bank with 160 accessions, resulting from the introduction of materials from several Brazilian collections. The characterization and evaluation of the germplasm regarding biomass quality may favor its use as a bioenergy source. In this sense, genetic diversity analysis among elephant grass genotypes are important, since the selection of parents for breeding programs and the management of variability in germplasm banks depends on the availability of accurate information on the degree of genetic divergence between the accessions (Pereira et al., 2008).

Currently, some research has been conducted to estimate the diversity among elephant grass genotypes based on morphological and agronomic (Shimoya et al., 2001; Shimoya et al., 2002; Rocha et al., 2017), cytogenetics (Techio et al., 2002) and molecular traits (Daher et al., 2002; Passos et al., 2005; Pereira et al., 2008; Azevedo et al., 2012; Wanjala et al., 2013). However, studies on genetic diversity in elephant grass for bioenergy purposes based on biomass quality are scarce in the literature.

Genetics and Molecular Research 16 (3): gmr16039803 
The objective of this study was to estimate the genetic diversity between elephant grass accessions based on morpho-agronomic and biomass quality traits and to identify promising genotypes for obtaining hybrids with high energetic biomass production capacity.

\section{MATERIAL AND METHODS}

\section{Deployment of the trial}

Trial was installed at experimental area of the State Agricultural College Antônio Sarlo, in Campos dos Goytacazes, RJ, under the geographical coordinates $21^{\circ} 44^{\prime} 47^{\prime \prime S}$ and $41^{\circ} 18^{\prime} 24^{\prime \prime} \mathrm{W}$, at $12 \mathrm{~m}$ in altitude. The region climate, according to Köppen classification, is Aw, hot and humid tropical with dry season in winter and rainy in summer and average annual rainfall of $1152 \mathrm{~mm}$. The soil in the area was classified as Dystrophic Yellow Argisol.

Trial was composed of 52 elephant grass genotypes from the Active Germplasm Bank of Elephant Grass (BAGCE) of the Embrapa Gado de Leite, located in Coronel Pacheco-MG (Table 1). The planting was carried out on March 28, 2008, by means of stem pieces, distributed in furrows of $10 \mathrm{~cm}$ depth. At planting, $100 \mathrm{~kg} / \mathrm{ha}$ of $\mathrm{P}_{2} \mathrm{O}_{5}$ were added. Irrigation was only offered during emergence of the plants, and at 50 days after planting (DAP) a fertilization with $25 \mathrm{~kg} / \mathrm{ha}$ of $\left(\mathrm{NH}_{4}\right)_{2} \mathrm{SO}_{4}$ and $\mathrm{KCl}$ was done.

Experimental design was a randomized block design with two replicates. Experimental plot was composed of two lines of $3 \mathrm{~m}$ spaced $0.5 \mathrm{~m}$ and $2 \mathrm{~m}$ between plots, considering as useful only $1.5 \mathrm{~m}$ of one of the lines, discarding the ends of each line. At 90 DAP, The genotypes were submitted to the uniformization cut (cutting close to the soil) followed by a cover fertilization with $25 \mathrm{~kg} / \mathrm{ha}$ of $\left(\mathrm{NH}_{4}\right)_{2} \mathrm{SO}_{4}$ and $\mathrm{KCl}$. The first cut for biomass quality analysis was conducted in May 2009, at the end of the rainy season.

\section{Evaluated traits}

The following morphoagronomic traits were evaluated: fresh weight per meter (FWM, $\mathrm{kg} / \mathrm{m})$, dry matter percentage $(\% \mathrm{DM})$, dry weight per meter (DWM, $\mathrm{kg} / \mathrm{m})$, number of plants per meter (NPM), plant height ( $\mathrm{PH}, \mathrm{m})$, and stalk diameter $(\mathrm{SD}, \mathrm{cm})$. For the analysis of biomass quality traits, dry material (leaf and stalk) was milled in a Willey mill with a 1-mm sieve and packed in an identified glass bottle. Biomass quality traits evaluated were: acid detergent fiber percentage $(\% \mathrm{ADF})$; cellulose percentage $(\% \mathrm{CEL})$; lignin percentage $(\% \mathrm{LIG})$; ash percentage (\%ASH); total nitrogen content (NC); and calorific value (PC), determined by the complete sample oxidation and measured by adiabatic calorimeter IKA model C-200. All biomass quality analyzes were performed according to the Van Soest methodology described in Silva and Queiroz (2002).

\section{Statistical analysis}

Components of variance and covariance were obtained using the following Bayesian multi-trait model:

$$
Y_{i j k}=\mu_{i}+b_{i j}+g_{i k}+\varepsilon_{i j k}
$$

where in $\mathrm{Y}_{\mathrm{ijk}}$ is the phenotypic value of the $\mathrm{i}$-th trait evaluated in the j-th block and in the k-th

Genetics and Molecular Research 16 (3): gmr16039803 
Table 1. Commercial name, code in the Active Germplasm Bank of Elephant Grass (BAGCE) and origin of the 52 elephant grass genotypes of the Embrapa Gado de Leite (CNPGL) evaluated in Campos dos Goytacazes, RJ.

\begin{tabular}{|c|c|c|}
\hline Code in the BAGCE & Commercial name & Origin \\
\hline BAGCE -1 & Elefante de Colômbia & IPEACO - Colômbia \\
\hline BAGCE -2 & Mercker & IPEACO -Água Limpa - MG \\
\hline BAGCE -3 & Três Rios & UFRRJ - Seropédica -RJ \\
\hline BAGCE -4 & Napier Volta Grande & UFRRJ - Seropédica -RJ \\
\hline BAGCE -5 & Mercker Santa Rita & UFRRJ - Seropédica -RJ \\
\hline BAGCE -6 & Pusa Napier $\mathrm{n}^{\circ} 2$ & Índia \\
\hline BAGCE -7 & Gigante de Pinda & Pindamonhangaba - SP \\
\hline BAGCE -8 & Napier $n^{\circ} 2$ & Goiás \\
\hline BAGCE -9 & Mercker S.E.A. & UFRRJ - Seropédica - RJ \\
\hline BAGCE -10 & Taiwan A-148 UF & UFRRJ - Seropédica - RJ \\
\hline BAGCE -11 & Porto Rico 534-B & UFV - Viçosa - MG \\
\hline BAGCE - 12 & Taiwan A-25 & UFRRJ - Seropédica - RJ \\
\hline BAGCE -13 & Albano & Colômbia \\
\hline BAGCE -14 & Híbrido Gig. Da Colômbia & Colômbia \\
\hline BAGCE - 15 & Pusa Gigante Napier & Índia \\
\hline BAGCE -16 & Elefante Híbrido 534-A & UFV - Viçosa-MG \\
\hline BAGCE - 17 & Costa Rica & Turrialba, Costa Rica \\
\hline BAGCE - 18 & Cubano Pinda & UFRRJ - Seropédica -RJ \\
\hline BAGCE -19 & Mercker Pinda & UFRRJ - Seropédica -RJ \\
\hline BAGCE - 20 & Mercker Pinda México & UFRRJ - Seropédica-RJ \\
\hline BAGCE - 21 & Mercker 86 - México & Colômbia \\
\hline BAGCE -22 & Taiwan A-144 & UFRRJ - Seropédica -RJ \\
\hline BAGCE -23 & Napier S.E.A. & UFRRJ - Seropédica -RJ \\
\hline BAGCE - 24 & Taiwan A-143 & UFRRJ - Seropédica -RJ \\
\hline BAGCE - 25 & Pusa Napier $\mathrm{n}^{\circ} 1$ & UFRRJ - Seropédica -RJ \\
\hline BAGCE -26 & Elefante de Pinda & Colômbia \\
\hline BAGCE -27 & Mineiro & IPEACO -Sete Lagoas - MG \\
\hline BAGCE -28 & Mole de Volta Grande & Volta Grande - SP \\
\hline BAGCE -29 & Porto Rico & IPEACO -Sete Lagoas - MG \\
\hline BAGCE -30 & Napier & Pedro Leopoldo-MG \\
\hline BAGCE -31 & Merckeron Comum & Pindamonhangada-SP \\
\hline BAGCE -32 & Teresópolis & UFRRJ - Seropédica-RJ \\
\hline BAGCE -33 & Taiwan A-46 J & UFRRJ - Seropédica-RJ \\
\hline BAGCE -34 & Duro de Volta Grande & UFRRJ - Seropédica-RJ \\
\hline BAGCE -35 & Merckeron Comum Pinda & UFRRJ - Seropédica-RJ \\
\hline BAGCE -36 & Turrialba & UFRRJ - Seropédica-RJ \\
\hline BAGCE -37 & Taiwan A-146 & UFRRJ - Seropédica-RJ \\
\hline BAGCE - 38 & Cameroon - Piracicaba & ESALQ - Piracicaba \\
\hline BAGCE -39 & Taiwan A-121 & UFRRJ - Seropédica-RJ \\
\hline BAGCE - 40 & Vrukwona & ESALQ - Piracicaba \\
\hline BAGCE -49 & P-241-Piracicaba & ESALQ - Piracicaba \\
\hline BAGCE -51 & IAC - Campinas & UFRRJ - Seropédica-RJ \\
\hline BAGCE -52 & Elefante Cachoeiro de Itapemirim & UFRRJ - Seropédica-RJ \\
\hline BAGCE -54 & Capim Cana D'África & IPEACS - Linhares-ES \\
\hline BAGCE -56 & Gramafante & Colômbia \\
\hline BAGCE -57 & Roxo & Lavras - ESAL-MG \\
\hline BAGCE -60 & Guaçu/IZ.2 & Nova Odessa-SP \\
\hline BAGCE -64 & King Grass & Cuba \\
\hline BAGCE -65 & Roxo Botucatu & UNESP - Botucatu \\
\hline BAGCE -67 & Vruckwona Africana & CENARGEM - Brasília \\
\hline BAGCE -68 & Cameroon & CENARGEM - Brasília \\
\hline BAGCE -91 & Pasto Panamá & Panamá \\
\hline
\end{tabular}

genotype; $\mu_{\mathrm{i}}$ is the systematic effect of the overall genotypic mean for the $\mathrm{i}$-th trait; $\mathrm{b}_{\mathrm{ij}}$ is the systematic effect of the $\mathrm{j}$-th block on the $\mathrm{i}$-th trait; $\mathrm{g}_{\mathrm{ik}}$ is the random effect of the $\mathrm{i}$-th trait on the k-th genotype; $\varepsilon_{\mathrm{ijk}}$ is the random error associated with observation $\mathrm{Y}_{\mathrm{ij \textrm {k }}}$. Under the Bayesian approach, the following joint data distribution (likelihood function) was adopted:

$$
y_{i j k} \mid \beta, g, G_{0}, R_{0} \sim N\left(x_{i j}^{\prime} \beta+z_{i k}^{\prime} g, \hat{\sigma}_{e}^{2}\right)
$$

Genetics and Molecular Research 16 (3): gmr16039803 
Where in: $\beta$ is the vector of the a priori probability of the systematic effects (overall mean and blocks effects); $\mathrm{g}=\left(\mathrm{g}_{\mathrm{ik}}\right) \sim \mathrm{N}\left(0, \mathrm{~A} \times \mathrm{G}_{0}\right)$ is the vector of the a priori probability of genotypic values where A is the relationship matrix between the genotypes and $G_{0}=\left[\begin{array}{ccc}\hat{\sigma}_{a 1}^{2} & \ldots & \hat{\sigma}_{a 1 i} \\ \vdots & \ddots & \vdots \\ \hat{\sigma}_{a i 1} & \ldots & \hat{\sigma}_{a i}^{2}\end{array}\right]$ is the genotypic covariance matrix; $\hat{\sigma}_{e}^{2}=\left(\varepsilon_{\mathrm{ijk}}\right) \sim \mathrm{N}\left(0, \mathrm{I} \times \mathrm{R}_{0}\right)$ is the a priori probability vector of residual values, where $\mathrm{I}$ is an identity matrix and $R_{0}=\left[\begin{array}{ccc}\hat{\sigma}_{e l}^{2} & \ldots & \hat{\sigma}_{e l i} \\ \vdots & \ddots & \vdots \\ \hat{\sigma}_{e i 1} & \ldots & \hat{\sigma}_{e i}^{2}\end{array}\right]$ is the residual covariance matrix taken as homogeneous; $\mathrm{x}_{\mathrm{ij}}$ and $\mathrm{z}_{\mathrm{ik}}$ are the incidence matrices associated with the systematic and random effects, respectively.

For the systematic effects vector, we assumed the following a priori normal distribution: $\beta \sim \mathrm{N}\left(\mathrm{b}_{0}, \mathrm{~V}_{\mathrm{b}}\right)$ where is a diagonal matrix for the $\beta$ variance, assuming $\mathrm{V}_{\mathrm{b}} \rightarrow$. For the genotypic $\left(G_{0}\right)$ and residual $\left(R_{0}\right)$ covariance matrices, Wishard distribution inverted $a$ priori will be assumed: $\mathrm{G}_{0} \sim \mathrm{W}_{3}^{-1}\left(\sum_{g}, n\right)$ and $R_{0} \sim \mathrm{W}_{3}^{-1}\left(\sum_{e}, n\right)$ where in $\sum_{g}$ and $\sum_{e}$ are scaled matrices and $\mathrm{n}$ is the degree of freedom of the parameter. A posteriori distribution for all parameters, which are dependent on the genotypic effects of the corresponding matrix but $p\left(\beta, g, G_{0}, R_{0} \mid y\right) \propto p\left(y \mid \beta, g, G_{0}, R_{0}\right) p\left(\beta \mid b_{0}, V_{b}\right) p\left(g \mid A \otimes G_{0}\right) p\left(G_{0} \mid \sum_{g}, n\right) p\left(R_{0} \mid \sum_{e}, n\right)$.

As Gibbs sampler is an iterative algorithm, it will be necessary to verify its convergence, which in this work will be verified by applying the Heidelberger and Welch (1983), Geweke (1992) and Raftery and Lewis (1992) criteria.

From the a posteriori $\beta$ (means vector) and $R_{0}$ (residual covariances matrix) estimates, Mahalanobis distance between each pair of genotypes was estimated, defined by:

$$
D_{i i^{\prime}}^{2}=\delta^{\prime} R_{0}^{-1} \delta
$$

Where in: $D_{\ddot{u}^{\prime}}^{2}$ is the Mahalanobis distance between the genotypes $i$ and $i^{\prime} ; \psi$ : residual variance and covariance matrix; $\delta^{\prime}=\left[d_{1} d_{2} \ldots d_{v}\right]$, being $\mathrm{d}_{\mathrm{j}}=Y_{\ddot{j}}-Y_{i^{\prime} j^{\prime}}$

Where in: $Y_{i j}$ is the measurement of the $\mathrm{i}$-th genotype in relation to $\mathrm{j}$-th variable.

The relative importance of evaluated traits for genetic dissimilarity was made through the $\mathrm{D}^{2}$ components relating to each trait in the total dissimilarity observed, using the criteria proposed by Singh (1981) based on statistic S.j', considering, in this case, that:

$$
D_{\ddot{u}^{\prime}}^{2}=\delta^{\prime} R_{0}^{-1} \delta=\sum_{j=1}^{n} \sum_{j^{\prime}=1}^{n} \omega_{j j^{\prime}} d_{j} d_{j^{\prime}}
$$

where in $\omega_{i j}$ is the element of the $j$-th line and $j$-th of the inverse column of the residual 
variance and covariance matrix $\left(R_{0}\right)$. All statistical analyses were performed with the GENES (Cruz, 2013) and R softwares (R Development, 2015).

\section{RESULTS AND DISCUSSION}

We considered 350,000 iterations in the Gibbs sampler algorithm for each parameter adopted, with a warm-up period (burn-in) of 50,000 iterations. To obtain an uncorrelated sample, we considered a spacing of five iterations (thinning) between the sampled points, which resulted in a final sample size 60,000. The Heidelberger and Welch (1983), Geweke (1992) and Raftery and Lewis (1992) criteria indicated the convergence of all chains for all parameters. Then, posteriori mean estimates were obtained for the components of variance and genotypic values used to estimate the genetic diversity among elephant grass genotypes (Table 2). Estimates of genotypic variance indicated a favorable condition for gains in all traits, which allows the identification of superior genetic material and the achievement of considerable gains with its introduction into a breeding program (Shimoya et al., 2002). Thus, identifying genotypes with satisfactory agronomic performance and biomass quality trait that qualify them as suitable for the bioenergy production is essential for a breeding program, since allied to the information on the genetic diversity of the genotypes, it contributes to the targeting of crosses aiming at obtaining individuals with high energetic potential.

\section{Genetic diversity as the morpho-agronomic traits}

Based on the Tocher clustering, it is possible to verify that genotype 21 (Mercker 86-México) is the only one that diverges from the other genotypes regarding the morphoagronomic traits, which allocated it into group II (Table 3). All other genotypes were allocated into group I, allowing the inference that these materials are genetically similar in relation to the morpho-agronomic traits evaluated. In the same way, by Ward's method two groups were formed, where the genotype Mercker 86-México was also allocated alone into a group and the other genotypes constituted a single group (Figure 1).

The genotype Mercker 86-México presented the highest means for \%DM (52\%) and DWM (5.44). According to Tew and Cobill (2009), sugarcane breeding programs for energy purposes aim to obtain cultivars containing $12 \%$ fiber and $75 \%$ water. The results obtained for the Mercker 86-México genotype show its superiority for the biomass production, since the mean $\% \mathrm{DM}$ obtained for the genotype was $52 \%$, i.e., $48 \%$ water. Among the genotypes from group I with better agronomic performance are genotype 36 (Turrialba), which presented higher \%DM (44\%), and genotype 60 (Guaçu/IZ.2), with higher means of FWM (14.47) and DWM (5.06). Based on these results, crosses between Mercker 86-México x Turrialba and Mercker 86-México x Guaçu/IZ.2 are promising for obtaining superior individuals for biomass production.

\section{Genetic diversity as biomass quality traits}

Biomass quality properties (calorific value and fiber, cellulose, lignin, and nitrogen contents) can influence the whole thermal biomass conversion process (Prochnow et al., 2009; Knoll et al., 2012; Na et al., 2016). It is important to mention that the biomass used as thermal energy source in the combustion process must have high concentrations of lignin and

Genetics and Molecular Research 16 (3): gmr16039803 
cellulose, high dry matter (i.e., low moisture contents) and calorific value, and low levels of ash and nitrogen (Jaradat, 2010; Na et al., 2016). Table 2. Means of the traits fresh weight plant $\mathrm{H}^{-1}(\mathrm{FWM}, \mathrm{kg} / \mathrm{m})$, dry matter percentage $(\% \mathrm{DM})$, dry weight plant ${ }^{-1}$
(DWM, kg/m), number of plants $\mathrm{m}^{-1}(\mathrm{NPM})$, plant height $(\mathrm{PH}, \mathrm{m})$, stalk diameter $(\mathrm{SD}, \mathrm{cm})$, acid detergent
fiber percentage (\%ADF), cellulose percentage (\%CEL), lignin percentage (\%LIG), ash percentage (\%ASH),
total nitrogen content $(\mathrm{NC})$ and calorific value (PC) evaluated in 52 elephant grass genotypes from Active
Germplasm Bank of Elephant Grass (BAGCE) of the Embrapa Gado de Leite.

\begin{tabular}{|c|c|c|c|c|c|c|c|c|c|c|c|c|}
\hline \multirow[t]{2}{*}{ Genotype } & \multicolumn{12}{|c|}{ Variable } \\
\hline & FWM & $\% \mathrm{DM}$ & DWM & NPM & PH & SD & $\%$ CEL & \%LIG & $\% \mathrm{ASH}$ & $\%$ ADF & $\mathrm{NC}$ & CAL \\
\hline 1 & 9.45 & 0.39 & 3.61 & 46.63 & 3.41 & 11.18 & 35.29 & 9.68 & 0.03 & 48.24 & 0.52 & 3901.04 \\
\hline 2 & 8.73 & 0.36 & 3.13 & 33.97 & 3.65 & 12.04 & 34.42 & 8.59 & 0.03 & 46.37 & 0.51 & 3897.44 \\
\hline 3 & 10.65 & 0.35 & 3.74 & 40.80 & 3.33 & 12.35 & 33.55 & 8.50 & 0.04 & 46.20 & 0.67 & 3894.47 \\
\hline 4 & 9.57 & 0.38 & 3.58 & 44.82 & 3.29 & 11.85 & 34.47 & 9.12 & 0.03 & 46.36 & 0.67 & 3904.34 \\
\hline 5 & 9.72 & 0.36 & 3.48 & 56.91 & 2.95 & 11.20 & 34.76 & 8.15 & 0.04 & 46.46 & 0.65 & 3905.28 \\
\hline 6 & 10.45 & 0.37 & 3.83 & 46.83 & 3.46 & 11.77 & 35.56 & 8.27 & 0.04 & 47.46 & 0.56 & 3901.61 \\
\hline 7 & 10.27 & 0.36 & 3.70 & 57.99 & 3.20 & 10.25 & 34.66 & 9.08 & 0.04 & 47.81 & 0.65 & 3904.19 \\
\hline 8 & 8.09 & 0.40 & 3.19 & 32.74 & 3.39 & 12.20 & 34.38 & 8.89 & 0.04 & 47.16 & 0.53 & 3890.81 \\
\hline 9 & 8.09 & 0.40 & 3.14 & 32.64 & 3.47 & 11.99 & 34.58 & 9.23 & 0.03 & 46.99 & 0.52 & 3892.66 \\
\hline 10 & 8.19 & 0.34 & 2.79 & 48.92 & 3.19 & 11.06 & 33.74 & 8.97 & 0.02 & 45.31 & 0.55 & 3901.71 \\
\hline 11 & 11.25 & 0.38 & 4.24 & 44.55 & 3.59 & 11.27 & 34.63 & 9.39 & 0.03 & 47.05 & 0.55 & 3897.64 \\
\hline 12 & 10.52 & 0.36 & 3.65 & 35.02 & 3.62 & 13.54 & 35.13 & 9.23 & 0.02 & 46.78 & 0.54 & 3904.11 \\
\hline 13 & 9.74 & 0.38 & 3.69 & 18.91 & 3.80 & 14.19 & 34.83 & 8.28 & 0.05 & 48.22 & 0.48 & 3884.48 \\
\hline 14 & 8.66 & 0.37 & 3.12 & 47.71 & 3.20 & 11.90 & 34.76 & 9.05 & 0.03 & 46.48 & 0.55 & 3906.78 \\
\hline 15 & 6.89 & 0.37 & 2.59 & 37.98 & 3.09 & 10.65 & 33.53 & 9.53 & 0.03 & 45.95 & 0.60 & 3892.00 \\
\hline 16 & 10.42 & 0.37 & 3.88 & 54.38 & 3.22 & 12.47 & 34.52 & 9.22 & 0.04 & 47.87 & 0.64 & 3905.65 \\
\hline 17 & 8.24 & 0.38 & 3.09 & 42.82 & 2.94 & 11.53 & 34.14 & 10.37 & 0.03 & 47.95 & 0.60 & 3898.14 \\
\hline 18 & 11.14 & 0.37 & 4.10 & 23.08 & 3.56 & 13.64 & 33.53 & 8.80 & 0.03 & 45.71 & 0.58 & 3887.45 \\
\hline 19 & 10.60 & 0.37 & 3.83 & 50.13 & 3.18 & 11.96 & 34.88 & 8.78 & 0.04 & 47.24 & 0.59 & 3907.57 \\
\hline 20 & 12.62 & 0.35 & 4.37 & 39.30 & 3.44 & 12.91 & 35.56 & 8.82 & 0.14 & 57.72 & 0.57 & 3900.96 \\
\hline 21 & 10.76 & 0.52 & 5.44 & 43.76 & 3.45 & 11.76 & 35.46 & 8.76 & 0.04 & 47.73 & 0.56 & 3903.52 \\
\hline 22 & 9.99 & 0.37 & 3.73 & 41.55 & 3.49 & 10.60 & 34.38 & 9.27 & 0.03 & 46.60 & 0.50 & 3897.21 \\
\hline 23 & 8.59 & 0.39 & 3.31 & 45.71 & 3.20 & 10.81 & 34.44 & 9.48 & 0.03 & 47.25 & 0.58 & 3898.72 \\
\hline 24 & 9.68 & 0.38 & 3.61 & 45.84 & 3.31 & 11.11 & 33.85 & 9.46 & 0.04 & 47.39 & 0.60 & 3896.96 \\
\hline 25 & 8.97 & 0.37 & 3.30 & 24.09 & 3.63 & 14.32 & 33.37 & 9.59 & 0.03 & 46.11 & 0.52 & 3887.24 \\
\hline 26 & 8.66 & 0.37 & 3.22 & 52.64 & 3.26 & 11.28 & 35.50 & 9.90 & 0.03 & 48.36 & 0.57 & 3901.63 \\
\hline 27 & 8.24 & 0.36 & 3.01 & 39.87 & 3.12 & 10.72 & 35.32 & 8.73 & 0.04 & 47.69 & 0.54 & 3891.75 \\
\hline 28 & 9.28 & 0.36 & 3.33 & 66.35 & 3.29 & 10.16 & 36.56 & 9.07 & 0.03 & 48.46 & 0.65 & 3912.03 \\
\hline 29 & 10.07 & 0.37 & 3.81 & 92.78 & 2.85 & 8.83 & 35.72 & 9.51 & 0.03 & 48.70 & 0.71 & 3917.01 \\
\hline 30 & 9.12 & 0.38 & 3.39 & 45.29 & 3.38 & 10.72 & 36.64 & 9.44 & 0.03 & 48.72 & 0.56 & 3901.36 \\
\hline 31 & 7.73 & 0.35 & 2.68 & 59.70 & 2.95 & 9.18 & 35.14 & 8.35 & 0.03 & 46.48 & 0.73 & 3910.11 \\
\hline 32 & 8.82 & 0.36 & 3.21 & 79.50 & 2.93 & 8.26 & 36.26 & 9.19 & 0.03 & 48.24 & 0.70 & 3915.21 \\
\hline 33 & 9.79 & 0.40 & 3.86 & 43.01 & 3.27 & 10.39 & 34.96 & 9.31 & 0.03 & 47.72 & 0.53 & 3898.05 \\
\hline 34 & 8.67 & 0.39 & 3.34 & 43.33 & 3.45 & 11.29 & 36.10 & 7.22 & 0.07 & 49.68 & 0.52 & 3892.71 \\
\hline 35 & 9.67 & 0.36 & 3.50 & 84.12 & 2.99 & 8.77 & 37.06 & 7.84 & 0.03 & 47.69 & 0.71 & 3918.60 \\
\hline 36 & 7.94 & 0.44 & 3.46 & 23.96 & 3.35 & 13.31 & 33.49 & 11.27 & 0.03 & 47.97 & 0.51 & 3884.97 \\
\hline 37 & 11.00 & 0.36 & 3.90 & 57.55 & 3.49 & 11.53 & 35.68 & 8.59 & 0.04 & 47.65 & 0.58 & 3903.70 \\
\hline 38 & 9.92 & 0.34 & 3.37 & 33.86 & 3.44 & 13.28 & 35.26 & 7.95 & 0.03 & 46.20 & 0.58 & 3892.73 \\
\hline 39 & 10.05 & 0.38 & 3.83 & 72.40 & 3.16 & 9.71 & 34.60 & 9.36 & 0.04 & 47.75 & 0.68 & 3908.42 \\
\hline 40 & 8.15 & 0.36 & 2.96 & 27.22 & 3.46 & 12.57 & 34.38 & 8.60 & 0.03 & 46.10 & 0.59 & 3890.09 \\
\hline 49 & 13.72 & 0.34 & 4.48 & 41.23 & 3.52 & 13.73 & 35.90 & 8.29 & 0.04 & 47.97 & 0.58 & 3888.85 \\
\hline 51 & 9.64 & 0.37 & 3.44 & 25.30 & 3.25 & 13.36 & 34.90 & 7.78 & 0.04 & 46.26 & 0.58 & 3891.50 \\
\hline 52 & 8.35 & 0.39 & 3.30 & 53.22 & 3.09 & 11.15 & 35.36 & 9.65 & 0.04 & 48.56 & 0.56 & 3895.54 \\
\hline 54 & 11.72 & 0.35 & 4.05 & 38.26 & 3.33 & 13.06 & 34.10 & 8.24 & 0.03 & 45.53 & 0.62 & 3897.48 \\
\hline 56 & 6.77 & 0.37 & 2.60 & 53.25 & 3.02 & 10.29 & 35.20 & 8.91 & 0.03 & 46.61 & 0.55 & 3900.55 \\
\hline 57 & 10.69 & 0.34 & 3.59 & 27.25 & 3.54 & 13.76 & 33.41 & 9.25 & 0.03 & 45.81 & 0.64 & 3889.32 \\
\hline 60 & 14.47 & 0.35 & 5.06 & 38.87 & 3.59 & 14.14 & 35.81 & 8.13 & 0.05 & 48.85 & 0.62 & 3886.49 \\
\hline 64 & 9.11 & 0.36 & 3.31 & 32.32 & 3.47 & 12.22 & 34.66 & 8.89 & 0.03 & 46.39 & 0.62 & 3892.90 \\
\hline 65 & 9.00 & 0.39 & 3.55 & 22.49 & 3.70 & 14.03 & 33.63 & 8.06 & 0.04 & 45.59 & 0.57 & 3879.31 \\
\hline 67 & 9.88 & 0.36 & 3.57 & 55.07 & 3.35 & 12.19 & 35.63 & 8.79 & 0.03 & 47.67 & 0.58 & 3902.59 \\
\hline 68 & 9.41 & 0.35 & 3.30 & 27.27 & 3.41 & 13.42 & 34.23 & 7.20 & 0.04 & 45.03 & 0.59 & 3890.62 \\
\hline 91 & 11.26 & 0.37 & 4.31 & 28.30 & 3.63 & 13.84 & 34.98 & 9.88 & 0.03 & 47.91 & 0.51 & 3892.24 \\
\hline
\end{tabular}

Similarly, to the clustering for the morpho-agronomic traits, both the Tocher and Ward clustered the genotypes into two groups (Table 4 and Figure 2). Group II consisted only of 
genotype 20 (Mercker Pinda México), while the other genotypes were allocated into group I. The genotype Mercker Pinda México presented the highest means for \%CEL and \%ADF (35.56 and $57.72 \%$, respectively), which may explain the fact that this genotype is divergent from the others based on the biomass quality traits. Thus, promising crosses to obtain transgressive segregating individuals would be those that meet parents with high energy potential and high production, such as Mercker Pinda México x Mercker 86-México and Mercker Pinda México $\mathrm{x}$ Turrialba.

Table 3. Tocher cluster applied to Mahalanobis distance of 52 elephant grass genotypes based on morphoagronomic traits.

\begin{tabular}{l|l}
\hline Group & Genotypes \\
\hline I & $1,2,3,4,5,6,7,8,9,10,11,12,13,14,15,16,17,18,19,20,22,23,24,25,26,27,28,29,30,31,32,33,34,35,36,37,38$, \\
& $39,40,41,42,43,44,45,46,47,48,49,50,51$ and 52 \\
\hline II & 21 \\
\hline
\end{tabular}

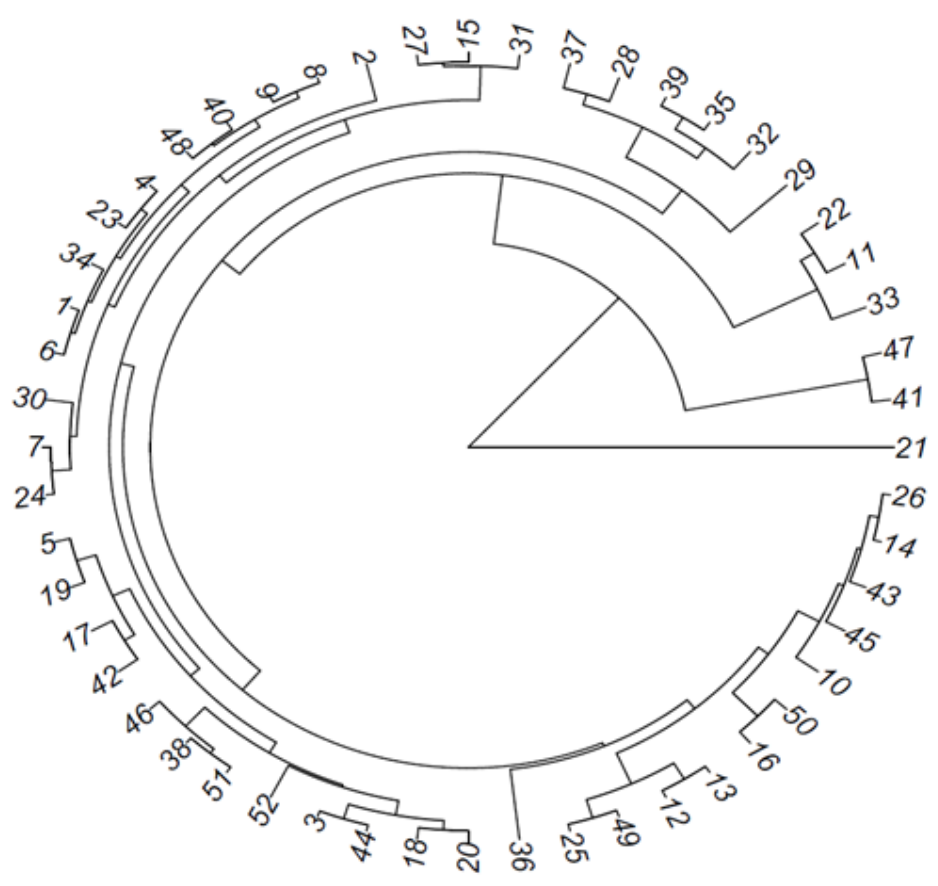

Figure 1. Ward cluster applied at Mahalanobis distance from 52 elephant grass genotypes based on morphoagronomic traits.

Table 4. Tocher cluster applied to Mahalanobis distance of 52 elephant grass genotypes based on biomass quality traits.

\begin{tabular}{l|l}
\hline Group & Genotypes \\
\hline I & $1,2,3,4,5,6,7,8,9,10,11,12,13,14,15,16,17,18,19,21,22,23,24,25,26,27,28,29,30,31,32,33,34,35,36,37,38,39$, \\
& $40,41,42,43,44,45,46,47,48,49,50,51$ and 52 \\
\hline II & 20 \\
\hline
\end{tabular}

Genetics and Molecular Research 16 (3): gmr16039803 


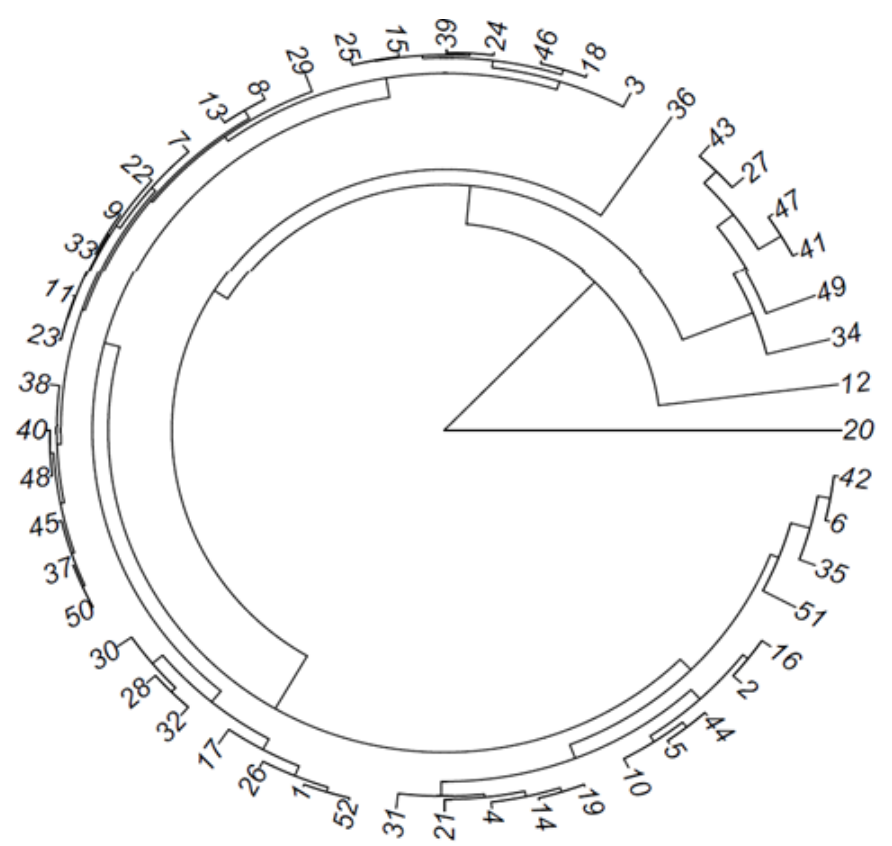

Figure 2. Ward cluster applied at Mahalanobis distance from 52 elephant grass genotypes based on biomass quality traits.

\section{Genetic diversity as morpho-agronomic biomass quality traits}

Tocher clustering based on morpho-agronomic and biomass quality traits allowed the formation of four groups (Table 5). Groups II, III and IV were composed by only one genotype each, constituted by genotypes 12,20 and 21, respectively. The remaining genotypes were allocated into group I. Although the genotypes differed little in relation to the values of $\mathrm{CAL}$, whose overall mean is $3898.23 \mathrm{cal} / \mathrm{g}$, the genotype 12 (Taiwan A-25), besides presenting satisfactory values of CAL (3904.11 cal/g), it also obtained the lowest \%ASH (0.022), Which is a good property for energy use. According to Rossi et al. (2014), biomass production and calorific value are correlated with fiber and ash content, and it is desirable to select materials that have high yield and fiber content, but with low ash content.

Table 5. Tocher cluster applied to Mahalanobis distance of 52 elephant grass genotypes based on morphoagronomic and biomass quality traits.

\begin{tabular}{l|l}
\hline Group & Genotypes \\
\hline I & $1,2,3,4,5,6,7,8,9,10,11,13,14,15,16,17,18,19,22,23,24,25,26,27,28,29,30,31,32,33,34,35,36$, \\
& $37,38,39,40,41,42,43,44,45,46,47,48,49,50,51$ and 52 \\
\hline II & 12 \\
\hline III & 20 \\
\hline IV & 21 \\
\hline
\end{tabular}

Three groups were formed by the Ward cluster, in which group II was formed by genotype 20 (Mercker Pinda México), group III by genotype 21 (Mercker 86-México) and the group I by the other genotypes (Figure 3). Again, by both cluster methods, it is possible to verify that the genotypes Mercker Pinda México and Mercker 86-México are divergent among

Genetics and Molecular Research 16 (3): gmr16039803 
themselves and from the others as to morpho-agronomic and biomass quality traits. This fact is confirmed by observing the mean values of the evaluated traits, where Mercker 86-Mexico obtained high means for the agronomic traits \%DM and DWM, while Mercker Pinda México presented higher means for the industrial traits \%CEL and \%ADF.

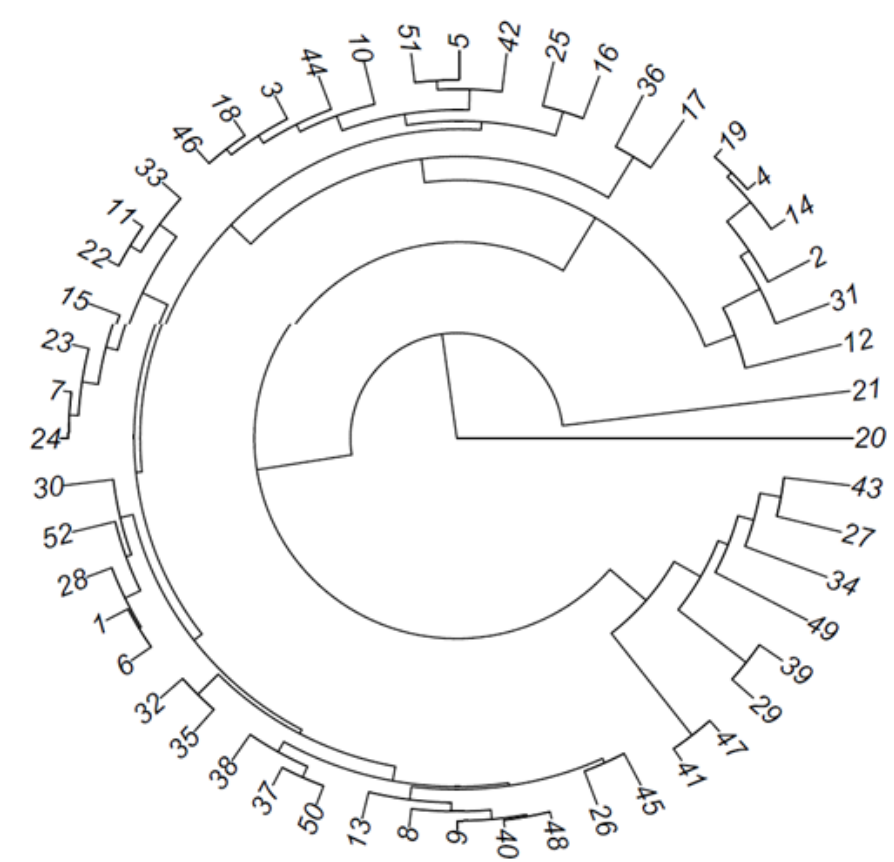

Figure 3. Ward cluster applied at Mahalanobis distance from 52 elephant grass genotypes based on morphoagronomic and biomass quality traits.

These results differ from those found in the literature, where a classification of the elephant grass germplasm variability is reported in four morphological groups: Napier, Merker, Cameroon, Anão, and interspecific hybrids (Pereira, 1992), or a division considering clustering results based on molecular analysis with the formation of two groups, where group I is constituted by morphologically closer accesses from the cultivars Napier and Merker, while group II presents greater morphological identification with the cultivar Cameroon (Passos et al., 2005; Pereira et al., 2008). From the results obtained in this study, the genotypes Mercker Pinda Mexico and Mexico-86 Mercker do not belong to the same group where Napier's access based on the biomass quality and morpho-agronomic traits have been allocated.

Rocha et al. (2017), evaluating 100 elephant grass accessions from BAGCE regarding the genetic diversity for bioenergy production, verified that they have potential for use as a bioenergetic feedstock, and that the accessions presented variability for the biomass quality traits higher than the morpho-agronomic traits, like the results obtained in this study.

Choosing parents should be made based on allelic complementarity and genetic divergence. Thus, crosses between divergent individuals belonging to different groups constitute the best way to obtain superior clones of elephant grass. Based on the Tocher and Ward clusters, it was possible to obtain information on the genetic variability between the

Genetics and Molecular Research 16 (3): gmr16039803 
accessions for agronomic traits and biomass quality, which together with the identification of superior genotypes for traits of interest, contributes to the definition of selection strategies of potential parents in breeding programs. Therefore, crosses between Mercker Pinda México x Mercker 86-México, Mercker Pinda México x Turrialba and Mercker 86-México x Taiwan A-25 can be carried out to obtain elephant grass hybrids for bioenergy production.

\section{Contribution of morpho-agronomic and biomass quality traits to genetic diversity}

Analysis of the relative importance of agronomic and biomass quality traits to genetic diversity based on the Singh (1981) criterion indicated that the CAL was the trait that contributed most to the genetic diversity between the accessions, with a relative importance of $36.86 \%$ (Figure 4 ). This shows that the genotypes present variability as to the potential of use as raw material for combustion. The \%ASH could have been discarded, since their relative importance is equal to 0 . The $\% \mathrm{ADF}(9.77 \%)$ had the second highest relative importance followed by NPM, \%DM, \%LIG and FWM, whose contributions to the genetic diversity were very similar. The other traits presented low contribution for discriminating the genotypes.

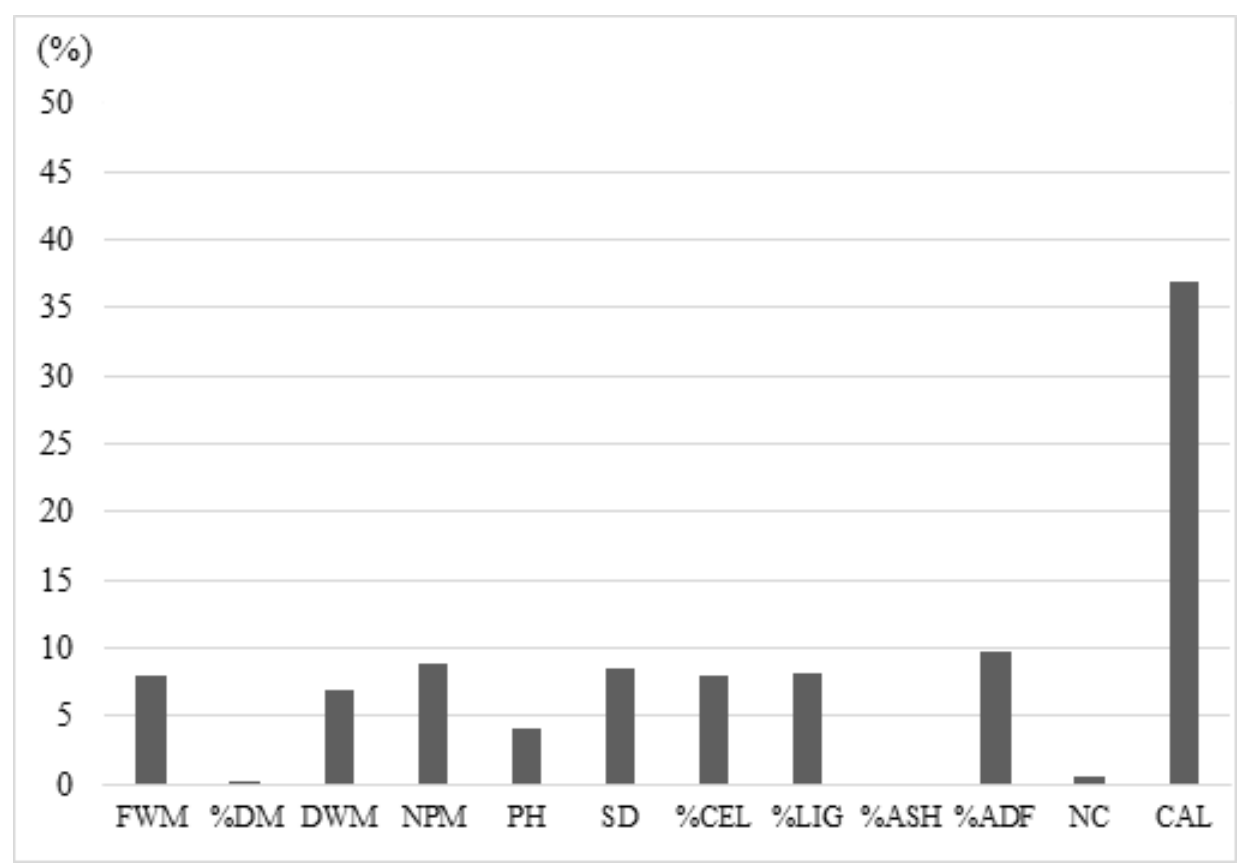

Figure 4. Relative contribution of agronomic and biomass quality traits to the genetic diversity of 52 elephant grass genotypes based on the Singh (1981) criterion.

Thus, it is possible to verify that most of the genetic variability among the genotypes is due to the differences in the traits expression related to the production of biomass. Therefore, the accesses evaluated have potential for use in elephant grass breeding programs for bioenergy purposes.

Genetics and Molecular Research 16 (3): gmr16039803 


\section{REFERENCES}

Azevedo ALS, Costa PP, Machado JC, Machado MA, et al. (2012). Cross-species amplification of Pennisetum glaucum microsatellite markers in Pennisetum purpureum and genetic diversity of Napier grass accessions. Crop Sci. 52: 1776-1785. https://doi.org/10.2135/cropsci2011.09.0480

Boehmel C, Lewandowski I and Claupein W (2008). Comparing annual and perennial energy cropping systems with different management intensities. Agric. Syst. 96: 224-236. https://doi.org/10.1016/j.agsy.2007.08.004

Cruz CD (2013). GENES - a software package for analysis in experimental statistics and quantitative genetics. Acta Sci. Agron. 35: 271-276. https://doi.org/10.4025/actasciagron.v35i3.21251

Daher RF, Pereira MG, Pereira AV and Amaral AT, Junior. (2002). Genetic divergence among elephantgrass cultivars assessed by RAPD markers in composite samples. Sci. Agric. 59: 623-627. https://doi.org/10.1590/S0103$\underline{90162002000400001}$

David K and Ragauskas AJ (2010). Switchgrass as an energy crop for biofuel production: a review of its ligno-cellulosic chemical properties. Energy Environ. Sci. 3: 1182-1190. https://doi.org/10.1039/b926617h

Fontoura CF, Brandão LE and Gomes LL (2015). Elephant grass biorefineries: towards a cleaner Brazilian energy matrix? J. Clean. Prod. 96: 85-93. https://doi.org/10.1016/j.jclepro.2014.02.062

Geweke J (1992). Evaluating the accuracy of sampling-based approaches to the calculation of posterior moments. In: Bernardo JM, Berger JO, David AP, Smith AFM (Ed.). Bayesian statistics. New York: Oxford University.

Gonçalves ACS, Daher RF, Vieira HD, Gravina GA, et al. (2012). Características morfológicas de inflorescências e sementes e potencial germinativo em variedades de capim-elefante de florescimento precoce. Natureza. Online (Bergh.) 10: 46-51.

Heidelberger P and Welch PD (1983). Simulation run length control in the presence of an initial transient. Oper. Res. Land. 31: 1109-1144. https://doi.org/10.1287/opre.31.6.1109

Jaradat AA (2010). Genetic resources of energy crops: biological systems to combat climate change. Aust. J. Crop Sci. 4: 309-323.

Knoll JE, Anderson WF, Strickland TC, Hubbard RK, et al. (2012). Low-input production of biomass from perennial grasses in the coastal plain of Georgia, USA. BioEnergy Res. 5: 206-214. https://doi.org/10.1007/s12155-011-9122-x

Morais RF, Souza JB, Leite JM, Soares LHB, et al. (2009). Elephant grass genotypes for bioenergy production by direct biomass combustion. Pesqui. Agropecu. Bras. 44: 133-140. https://doi.org/10.1590/S0100-204X2009000200004

$\mathrm{Na}$ C, Fedenko JR, Sollenberger LE and Erickson JE (2016). Harvest management affects biomass composition responses of 4 perennial bioenergy grasses in the humid subtropical USA. Glob. Change Biol. Bioenergy 8: 1150-116. https:// doi.org/10.1111/gcbb.12319

Nass LL, Pereira PAA and Ellis D (2007). Biofuels in Brazil: an overview. Crop Sci. 47: 2228-2237. https://doi.org/10.2135/ cropsci2007.03.0166

Passos LP, Machado MA, Vidigal MC, et al. (2005). Molecular characterization of elephantgrass accessions through RAPD markers. Cienc. Agrotec. 29: 568-574. https://doi.org/10.1590/S1413-70542005000300009

Pereira AV (1992). Escolha de variedades de capim-elefante. In: Simpósio sobre Manejo de Pastagem, 10., 1992, Piracicaba. Anais... Fundação de Estudos Agrários Luiz de Queiroz, Piracicaba, 45-62.

Pereira AV, Machado MA, Azevedo ALS, Nascimento CS, et al. (2008). Diversidade genética entre acessos de capimelefante obtida com marcadores moleculares. R. Bras. Zootec. 37: 1216-1221.

Prochnow A, Heiermann M, Plöchl M, Amon T, et al. (2009). Bioenergy from permanent grassland - a review: 2. Combustion. Bioresour. Technol. 100: 4945-4954.

Ra K, Shiotsu F, Abe J and Morita S (2012). Biomass yield and nitrogen use efficiency of cellulosic energy crops for ethanol production. Biomass Bioenergy 37: 330-334. https://doi.org/10.1016/j.biombioe.2011.12.047

Raftery AL and Lewis SM (1992). Comment: one long run with diagnostics: implementation strategies for Markov chain Monte Carlo. Stat. Sci. 7: 493-497. https://doi.org/10.1214/ss/1177011143

Rocha JRASC, Machado JC, Carneiro PCS, Carneiro JC, et al. (2017). Bioenergetic potential and genetic diversity of elephantgrass via morpho-agronomic and biomass quality traits. Ind. Crops Prod. 95: 485-492. https://doi. org/10.1016/j.indcrop.2016.10.060

Rossi DA, Menezes BRS, Daher RF, Gravina GA, et al. (2014). Canonical correlations in elephant grass for energy purposes. Afr. J. Biotechnol. 13: 3666-3671. https://doi.org/10.5897/AJB2014.13915

Shimoya A, Ferreira RP, Pereira AV, Cruz CD, et al. (2001). Comportamento morfo-agronômico de genótipos de capimelefante. Rev. Ceres 48: 141-158.

Shimoya A, Cruz CD, Ferreira RP, Pereira AV, et al. (2002). Divergência genética entre acessos de um banco de germoplasma de capim elefante. Pesqui. Agropecu. Bras. 37: 971-980. https://doi.org/10.1590/S0100-204X2002000700011

Genetics and Molecular Research 16 (3): gmr16039803 
Silva DJ and Queiroz AC (2002). Análises de alimentos (métodos químicos e biológicos). 3rd edn. Editora UFV, Vicosa. Singh D (1981). The relative importance of characters affecting genetic divergence. Indian J. Genet. Plant Breed. 41: 237-245.

Techio VH, Davide LC, Pereira AV and Bearzoti E (2002). Cytotaxonomy of some species and of interspecific hybrids of Pennisetum (Poaceae, Poales). Genet. Mol. Biol. 25: 203-209. https://doi.org/10.1590/S1415-47572002000200014

Tew TL and Cobill RM (2009). Genetic improvement of sugarcane (Saccharum spp.) as an energy crop. In: Genetic Improvement of Bioenergy Crops (Vermerris W, ed.). Springer, New York.

Wanjala BW, Obonyo M, Wachira FN, Muchugi A, et al. (2013). Genetic diversity in Napier grass (Pennisetum purpureum) cultivars: implications for breeding and conservation. AoB Plants 5: plt022. PubMed https://doi.org/10.1093/aobpla/ plt022 